SAR (Soedirman Accounting Review): Journal of Accounting and Business

Journal Homepage: http://jos.unsoed.ac.id/index.php/sar/

\title{
FINTECH DAN E COMMERCE UNTUK MENDORONG PERTUMBUHAN UMKM DAN INDUSTRI KREATIF
}

\author{
Nefo Indra Nizar ${ }^{1 *}$, Iman Lubis ${ }^{2}$ \\ Universitas Pamulang, Indonesia \\ *Email corresponding author: nefoindra@gmail.com
}

\begin{abstract}
The purpose of this study is to dig deeper into the role of fintech and e-commerce on the growth of MSMEs and Creative Industries through the assessment of e-business models on Modalku and Blanja .com in encouraging the growth of MSMEs and creative industries. The method used is a literature study by conducting several exposures on policies, procedures, implementation and evaluation for the Modalku (fintech) and Blanja.com (e-commerce) platforms. The results obtained are government policies to support and facilitate the formation of fintech and ecommerce platforms, company procedures that maintain the confidentiality and security for e-commerce and legal certainty at fintech to support the safe use of these platforms. The implementation carried out as measured by four criteria, namely infrastructure management, product innovation, customer relationship, and financial aspects, really helps MSMEs and creative industries to obtain funds and distribute products to the market.
\end{abstract}

Keywords: Infrastructure Management, Product innovation, Customer Relationship, dan Financial Aspect

\begin{abstract}
Abstrak
Tujuan Penelitian ini untuk menggali lebih dalam mengenai peran fintech dan e-commerce terhadap pertumbuhan UMKM dan Industri Kreatif melalui penilaian e-bisnis model pada Modalku dan Blanja .com dalam mendorong pertumbuhan UMKM dan industry kreatif. Metode yang digunakan adalah studi pustaka dengan melakukan beberapa paparan mengenai kebijakan, prosedur, pelaksanaan dan evaluasi untuk platform Modalku (fintech) dan Blanja.com (e-commerce). Hasil yang didapat adalah kebijakan pemerintah mendukung dan mempermudah terbentuknya platform fintech dan e-commerce, prosedur perusahaan yang menjaga kerahasiaan dan keamanan untuk e-commerce dan kepastian hukum di fintech mendukung amannya penggunaan platform tersebut. Pelaksanaan yang dilakukan yang diukur dengan empat kriteria yaitu infrastructure management, product innovation, customer relationship, dan financial aspect sangat membantu UMKM dan Industri kreatif untuk mendapatkan dana dan menyalurkan produk ke pasar.
\end{abstract}

Kata Kunci: Manajemen Infrastruktur, Inovasi Produk, Hubungan Pelanggan, dan Aspek Keuangan

\section{PENDAHULUAN}

UMKM merupakan salah satu sektor utama di dalam menyumbang pertumbuhan ekonomi. Sementara industri kreatif merupakan sektor ekonomi potensial dan strategis yang saat ini terus berkembang dan 
mampu memberikan kontribusi terhadap Produk Domestik Bruto. Untuk dapat mendorong pertumbuhan UMKM dan Industri Kreatif, diperlukan akses pembiayaan yang mudah dan cepat, serta tersedianya pasar yang luas yang tidak saja bersifat lokal, tetapi juga mampu menyalurkan hasil produksi UMKM dan Industri Kreatif lintas negara. Dengan adanya kemajuan teknologi berbasis internet, dengan munculnya perusahaan start up financial technologi dan platform e Commerce dapat memberikan solusi terhadap pembiayaan dan pasar untuk UMKM dan Industri Kreatif.

Usaha Mikro, Kecil, dan Menengah (UMKM) memiliki definisi yang berbeda pada setiap literatur menurut beberapa instansi atau lembaga bahkan undang-undang. Sesuai dengan UndangUndang nomor 20 tahun 2008 tentang Usaha Mikro, Kecil, dan Menengah, UMKM didefinisikan sebagai berikut: 1. Usaha mikro adalah usaha produktif milik orang perorangan dan/atau badan usaha perorangan yang memenuhi kriteria Usaha Mikro sebagaimana diatur dalam Undang-Undang ini. 2. Usaha Kecil adalah usaha ekonomi produktif yang berdiri sendiri, yang dilakukan oleh orang perorangan atau badan usaha yang bukan merupakan anak perusahaan atau bukan cabang perusahaan yang dimiliki, dikuasai, atau menjadi bagian baik langsung maupun tidak langsung dari Usaha Menengah atau Usaha Besar yang memenuhi kriteria Usaha Kecil sebagaimana dimaksud dalam Undang-Undang ini. 3. Usaha Menengah adalah usaha ekonomi produktif yang berdiri sendiri, yang dilakukan oleh orang perorangan atau badan usaha yang bukan merupakan anak perusahaan atau cabang perusahaan yang dimiliki, dikuasai, ataupun menjadi bagian baik langsung maupun tidak langsung dengan Usaha Kecil atau Usaha Besar dengan jumlah kekayaan bersih atau hasil penjualan tahunan sebagaimana diatur dalam UndangUndang ini. Berdasarkan kekayaan dan hasil penjualan, menurut Undang-Undang Nomor 20 tahun 2008 pasal 6, kriteria usaha mikro yaitu: 1. "Memiliki kekayaan bersih paling banyak Rp 50.000.000,00 (lima puluh juta rupiah) tidak termasuk tanah dan bangunan tempat usaha"; atau 2. "Memiliki hasil penjualan tahunan paling banyak Rp 300.000.000,00 (tiga ratus juta rupiah)". Kriteria usaha kecil adalah sebagai berikut: 1. "Memiliki kekayaan bersih lebih dari Rp 50.000.000,00 (lima puluh juta rupiah) sampai dengan paling banyak Rp 500.000.000,00 (lima ratus juta rupiah) tidak termasuk tanah dan bangunan tempat usaha"; atau 2. "Memiliki hasil penjualan tahunan lebih dari Rp 300.000.000,00 (tiga ratus juta rupiah) sampai dengan paling banyak Rp 2.500.000.000,00 (dua milyar lima ratus juta rupiah)". Sedangkan kriteria usaha menengah adalah sebagai berikut: 1. "Memiliki kekayaan bersih lebih dari Rp 500.000.000,00 (lima ratus juta rupiah) sampai dengan paling banyak Rp 10.000.000.000,00 (sepuluh milyar rupiah) tidak termasuk tanah dan bangunan tempat usaha"; atau 2. "Memiliki hasil penjualan tahunan lebih dari Rp 2.500.000.000,00 (dua milyar lima ratus juta rupiah) sampai dengan paling banyak Rp 50.000.000.000,00 (lima puluh milyar rupiah)". 
Industri kreatif adalah industri yang menghasilkan output dari pemanfaatan kreativitas, keahlian dan bakat individu untuk menciptakan nilai tambah,lapangan pekerjaan dan peningkatan kualitas hidup (Ekonomi Kreatif: Kekuatan Baru Indonesia Menuju 2025).

\section{Aplikasi dan pengembangan permainan}

Beberapa pengembang di Indonesia untuk aplikasi dan game bermunculan disebabkan semakin meningkatnya penetrasi smartphone di Indonesia. Namun, sektor ini masih mengalami beberapa kendala yaitu sedikitnya minat investor pada sektor ini dan belum adanya kebijakan proteksi yang memihak pada kepentingan developer domestik.

\section{Arsitektur}

Arsitektur sebagai salah satu subsektor ekonomi kreatif memiliki peranan yang penting dari sisi kebudayaan dan pembangunan. Dari sisi budaya, arsitektur mampu menunjukkan karakter budaya bangsa Indonesia yang beraneka ragam. Dari sisi pembangunan, jelas arsitektur berperan dalam perancangan pembangunan sebuah kota. Menurut Bekraf, sektor ini masih mengalami kendala dari sisi jumlah arsitek yang ada. Saat ini jumlah arsitek yang ada mencapai 15.000 orang, tidak sebanding dengan populasi penduduk Indonesia yang mencapai 250 juta orang.

\section{Desain Produk}

Hasil dari subsektor ini sering kita jumpai sehari-hari. Ada jemari-jemari terampil dari desainer produk yang mengkreasikan sebuah produk dengan menggabungkan unsur fungsi dan estetika sehingga mempunyai nilai tambah bagi masyarakat. Tren dari industri ini meningkat seiring dengan bertambahnya populasi usia produktif yang membentuk interaksi antara pelaku industri dengan dengan pasar. Selain itu, industri ini juga didorong oleh apresiasi masyarakat yang semakin tinggi terhadap produk berkualitas.

\section{Fesyen}

Fesyen merupakan subsektor industri kreatif yang berjalan sangat dinamis. Berbagai tren fesyen bermunculan setiap tahunnya karena inovasi dan produktivitas desainer. Saat ini, daya saing fesyen meningkat cukup signifikan di tingkat global. Data dari Kementerian Perindustrian tahun 2016 mencatat, nilai ekspor dari industri fesyen Indonesia mencapai USD 11, 7 miliar.

\section{Desain Interior}

Menurut Bekraf, selama 20 tahun terakhir ini, sektor desain interior menunjukkan perkembangan yang sangat pesat. Penggunaan jasa desainer untuk merancang interior hunian, hotel hingga 
perkantoran pun semakin meningkat. Apresiasi masyarakat terhadap bidang ini juga semakin baik. Namun, ada beberapa hal yang masih perlu menjadi kendala dari sektor ini yaitu proteksi terhadap para pelaku kreatif desain interior di pasar domestik, adanya sertifikasi untuk menciptakan standar, dan perlindungan hak cipta.

\section{Desain Komunikasi Visual}

Desain Komunikasi Visual atau yang sering dikenal dengan sebutan DKV merupakan ilmu yang mempelajari konsep komunikasi dengan memanfaatkan elemen visual sebagai cara untuk mencapai tujuan tertentu. Desain Komunikasi Visual mempunyai peranan yang penting dalam mendukung pertumbuhan bisnis swasta, pemilik merek, bahkan program-program pemerintah.

\section{Seni Pertunjukan}

Indonesia adalah negara yang kaya akan seni pertunjukan. Kesenian ini ada sejak lama dalam bentuk wayang, teater, ludruk, tari dan masih banyak lagi. Kesenian tersebut menyebar ke seluruh Indonesia dengan ciri khasnya masing-masing.

\section{Film, Animasi dan Video}

Industri perfilman saat ini sedang mengalami perkembangan yang positif. Berbagai judul film silih berganti menghiasi layar bioskop Indonesia. Animasi juga menunjukkan perkembangan yang positif. Kita bisa melihat munculnya serial animasi di tv nasional yang sebelumnya hanya diisi oleh animasianimasi dari luar negeri. Permasalahan yang muncul pada sektor ini diantaranya adalah masalah sumber daya manusia, tidak meratanya jumlah bioskop yang ada di Indonesai sampai dengan masalah klasik yakni pembajakan.

\section{Fotografi}

Perkembangan industri fotografi digandrungi oleh minat anak muda sekarang yang semakin tinggi terhadap dunia fotografi. Banyaknya minat tersebut dikarenakan semakin berkembangnya sosial media dan harga kamera yang semakin terjangkau.

\section{Kriya}

Kriya merupakan segala kerajinan yang berbahan kayu, logam, kulit, kaca, keramik, dan tekstil. Indonesia merupakan negara yang kaya akan kerajinan seni kriya. Hasil kerajinan tersebut selain untuk pasar domestik, banyak juga yang ekspor ke luar negeri. Sementara itu, faktor ketersediaan bahan baku menjadi masalah dan permodalan juga menjadi masalah klasik lainnya. 


\section{Kuliner}

Kuliner memiliki potensi yang kuat untuk berkembang. "Data dari Bekraf menyebutkan bahwa sektor ini menyumbang kontribusi 30\% dari total sektor pariwisata dan ekonomi kreatif". Beberapa hal yang masih menjadi perhatian pemerintah yaitu akses perizinan satu pintu, panduan bisnis dan perizinan, hingga pendampingan hokum dalam proses pendirian usaha.

\section{Musik}

Musik merupakan industri yang sangat dinamis. Perkembangan terbaru saat ini di dunia musik adalah semakin banyaknya platform pembelian musik digital yang mudah dan murah sehingga mengurangi aksi pembajakan.

\section{Penerbitan}

Industri penerbitan berkontribusi dalam membangun kekuatan intelektualitas bangsa. Meskipun pangsa pasar industri ini tidak sebesar sektor yang lain, namun industri ini punya potensi juga. Industri penerbitan terus berupaya untuk menyesuaikan dengan perkembangan zaman dengan hadirnya produk penerbitan seperti buku dan majalah dalam bentuk digital.

\section{Periklanan}

Periklanan merupakan suatu penyajian materi yang berisi pesan persuasif kepada masyarakat untuk mempromosikan produk atau jasa. Konten-konten iklan biasanya dibuat khusus oleh agensi iklan. Menurut Bekraf, periklanan merupakan subsektor industri kreatif yang memiliki daya sebar paling tinggi. Hal ini tidak terlepas dari sinergi dengan para pemilik modal yang memasarkan produk.

\section{Seni rupa}

Di Indonesia seni rupa sudah berkembang dengan cukup baik. Tercatat ada beberapa acara pameran seni rupa rutin diselenggarakan seperti Jogja Biennale, Jakarta Biennale, Art Jog, dan OK Video Festival.

\section{Televisi dan Radio}

Di tengah arus informasi digital yang semakin masif, televisi dan radio masih menunjukkan eksistensinya. Peranan kedua industri ini pun cukup besar dengan nilai mencapai 3,17\% dari Produk Domestik Bruto (PDB). Dari sisi ketenagakerjaan, industri televisi dan radio menduduki peringkat ke-6 terbesar dalam kontribusi terhadap total tenaga kerja industri kreatif di Indonesia. 
Tabel 1. PDB Ekonomi Kreatif dan PDB Bruto

\begin{tabular}{|c|c|c|c|c|c|}
\hline & Tahun & \multirow{2}{*}{2014} & \multirow{2}{*}{2015} & \multirow{2}{*}{2016} & \multirow{2}{*}{ Totals } \\
\hline Tipe Nilai & Subsektor & & & & \\
\hline & Aplikasi dan Game Developer & $11,222.20$ & $11,787.90$ & $12,738.00$ & $35,748.10$ \\
\hline & Arsitektur & $13,552.30$ & $14,449.10$ & $15,323.50$ & $43,324.90$ \\
\hline & Desain Interior & $1,040.40$ & $1,103.80$ & $1,169.20$ & $3,313.40$ \\
\hline & Desain Komunikasi Visual & 363.70 & 401.10 .00 & 437.10 .00 & $1,201.90$ \\
\hline & Desain Produk & $1,654.10$ & $1,687.70$ & $1,817.20$ & $5,159.00$ \\
\hline & Fashion & $119,172.20$ & $122,480.50$ & $127,435.30$ & $369,088.00$ \\
\hline & Film, Animasi, dan Video & 948.00 .00 & $1,011.20$ & $1,113.20$ & $3,072.40$ \\
\hline & Fotografi & $2,804.80$ & $2,980.40$ & $3,185.80$ & $8,971.00$ \\
\hline & Kriya & $99,235.00$ & $103,743.60$ & $106,098.30$ & $309,076.90$ \\
\hline & Kuliner & $281,711.50$ & $292,978.70$ & $307,800.60$ & $882,490.80$ \\
\hline & Musik & $2,739.10$ & $2,937.80$ & $3,160.70$ & $8,837.60$ \\
\hline & Penerbitan & $38,021.00$ & $39,875.40$ & $41,309.80$ & $119,206.20$ \\
\hline & Periklanan & $4,980.10$ & $5,284.90$ & $5,658.30$ & $15,923.30$ \\
\hline & Seni Pertunjukan & $1,644.60$ & $1,743.70$ & $1,910.00$ & $5,298.30$ \\
\hline & Seni Rupa & $1,406.80$ & $1,494.60$ & $1,561.90$ & $4,463.30$ \\
\hline & Televisi dan Radio & $54,018.40$ & $58,551.90$ & $64,600.50$ & $177,170.80$ \\
\hline PDB Ekonomi Kreatif & & $657,673.90$ & $686,662.60$ & $720,632.70$ & $2,064,969.20$ \\
\hline PDB Ekonomi Kreatif Atas Harga Dasar & & $634,514.20$ & $662,512.30$ & $695,319.40$ & $1,992,345.90$ \\
\hline PDB Non-Ekonomi Kreatif & & 7,907,192.70 & $8,295,848.70$ & $8,712,401.70$ & $24,915,443.10$ \\
\hline $\begin{array}{c}\text { Pajak Dikurang Subsidi Atas Produk } \\
\text { Ekonomi Kreatif }\end{array}$ & & $23,159.70$ & $24,150.30$ & $25,313.30$ & $72,623.30$ \\
\hline Produk Domestik Bruto & & $8,564,866.60$ & $8,982,511.30$ & $9,433,034.40$ & $26,980,412.30$ \\
\hline Totals & & $18,421,921.30$ & $19,314,197.50$ & $20,282,020.90$ & $58,018,139.70$ \\
\hline
\end{tabular}

Sumber: Bekraf

PDB Ekonomi Kreatif mengalami peningkatan dari tahun 2014, 2015 dan 2016 sebesar $\$ 657,673.90, \$ 686,662,60$, dan $\$ 720,632.70$ dengan total selama tiga tahun sebesar $\$ 2,064,969.20$. Penyumbang PDB Kreatif terbesar pada kuliner sebesar $\$ 882,490.80$ namun penyumbang terkecil berasal dari Desain Komunikasi Visual sebesar \$1,201.90.

Kontribusi PDB Ekonomi Kreatif kepada PDB di tahun 2014 adalah \$657,673.90 dari $\$ 8,564,866.60$ yang merupakan $7,68 \%$ dari PDB; di tahun 2015 adalah $\$ 662,512.30$ dari $\$ 8,564,866.60$ yang merupakan 7,74\% dari PDB; di tahun 2016 adalah $\$ 695,319.40$ dari $\$ 9,433,034.40$ yang merupakan 7,4\% dari PDB. Total tiga tahun sebesar $\$ 1,992,345.90$ dari $\$ 26,980,412.30$ yang merupakan 7,4\% PDB total tiga tahun. 
Soedirman Accounting Review, Juni 2020, Vol. 05 No. 01 Tahun 2020, Hal 18 - 39

Tabel 2. 16 Subsektor Industri Kreatif Provinsi-provinsi di Indonesia

\begin{tabular}{|c|c|c|c|c|c|c|c|c|c|c|c|}
\hline \multirow[b]{2}{*}{ Subsektor } & \multicolumn{10}{|c|}{2016} & \multirow[b]{2}{*}{ Totals } \\
\hline & $\begin{array}{l}\text { Provinsi } \\
\text { Banten }\end{array}$ & \begin{tabular}{|l|} 
Provinsi \\
DI \\
Yogyakar
\end{tabular} & $\begin{array}{l}\text { Provinsi } \\
\text { DKI } \\
\text { Jakarta }\end{array}$ & $\begin{array}{l}\text { Provinsi } \\
\text { Jawa } \\
\text { Barat }\end{array}$ & $\begin{array}{l}\text { Provinsi } \\
\text { Jawa } \\
\text { Tengah }\end{array}$ & $\begin{array}{l}\text { Provinsi } \\
\text { Jawa } \\
\text { Timur }\end{array}$ & $\begin{array}{l}\text { Pulau } \\
\text { Bali dan } \\
\text { Nusa }\end{array}$ & \begin{tabular}{l|} 
Pulau \\
Kalimant \\
an
\end{tabular} & \begin{tabular}{|l|} 
Pulau \\
Sulawesi, \\
Maluku,
\end{tabular} & $\begin{array}{l}\text { Pulau } \\
\text { Sumatera }\end{array}$ & \\
\hline Aplikasi dan Game & 884 & 543 & 1,185 & 3,036 & 1,133 & 2,558 & 384 & 395 & 453 & 1,87 & 12,441 \\
\hline Arsitektur & 138 & 320 & 610 & 728 & 577 & 637 & 561 & 504 & 772 & 893 & 5,74 \\
\hline Desain Interior & 29 & 83 & 122 & 141 & 93 & 113 & 44 & 38 & 60 & 75 & 79 \\
\hline Desain Komunikasi & 14 & 165 & 69 & 88 & 135 & 71 & 24 & 14 & 11 & 25 & 616 \\
\hline Desain Produk & 65 & 226 & 657 & 691 & 751 & 380 & 77 & 112 & 64 & 344 & 3,367 \\
\hline Fashion & 40,222 & 22,5 & 96,209 & 228,848 & 217,605 & 199,746 & 49,196 & 56,955 & 87,589 & 232,118 & $1,230,988$ \\
\hline Film, Animasi, dan & 47 & 106 & 341 & 406 & 364 & 365 & 92 & 119 & 110 & 468 & 2,418 \\
\hline Fotografi & 805 & 1,152 & 1,281 & 6,002 & 6,583 & 6,719 & 1,764 & 2,197 & 4,542 & 9,391 & 40,436 \\
\hline Kriya & 21,965 & 35,832 & 22,286 & 150,104 & 296,033 & 255,684 & 162,318 & 42,668 & 70,568 & 137,051 & $1,194,509$ \\
\hline Kuliner & 230,267 & 105,568 & 342,44 & $1,086,602$ & 862,413 & 997,862 & 203,98 & 295,984 & 360,362 & $1,065,482$ & $5,550,960$ \\
\hline Musik & 1,002 & 802 & 1,943 & 6,019 & 5,037 & 5,526 & 966 & 2,108 & 2,99 & 7,849 & 34,242 \\
\hline Penerbitan & 2,742 & 3,105 & 11,257 & 13,669 & 13,345 & 16,805 & 2,828 & 3,385 & 5,445 & 10,915 & 83,496 \\
\hline Periklanan & 81 & 183 & 1,292 & 343 & 231 & 376 & 91 & 71 & 84 & 303 & 3,055 \\
\hline Seni Pertunjukan & 603 & 676 & 1,161 & 4,53 & 3,072 & 4,29 & 953 & 768 & 1,035 & 2,684 & 19,772 \\
\hline Seni Rupa & 421 & 899 & 1,131 & 2,363 & 2,442 & 3,029 & 3,643 & 593 & 812 & 1,711 & 17,044 \\
\hline Televisi dan Radio & 100 & 70 & 110 & 533 & 341 & 987 & 169 & 427 & 440 & 767 & 3,944 \\
\hline Totals & 299,385 & 172,23 & 482,094 & $1,504,103$ & $1,410,155$ & $1,495,148$ & 427,09 & 406,338 & 535,337 & $1,471,946$ & 203,826 \\
\hline
\end{tabular}

Sumber: Bekraf

Di atas adalah table 2 yang menggambarkan 16 subsektor industri kreatif di Indonesia. Menurut data di 2016 tidak semua provinsi ternyata memiliki banyak industri kreatif. Provinsi-proinsi tersebut adalah Provinsi Banten, Provinsi DI Yogyakarta, Provinsi DKI Jakarta, Provinsi Jawa Barat, Provinsi Jawa Tengah, Provinsi Jawa Timur, Pulau Bali dan Nusa, Pulau Kalimantan, Pulau Sulawesi, Maluku, dan Pulau Sumatera.

Provinsi Pada tahun 2016, Provinsi Jawa Barat memiliki unit terbanyak sebesar 3,036 usaha untuk pembuatan aplikasi dan game dibandingkan dengan provinsi yang lain dan Pulau Bali dan Nusa yang paling sedikit sebesar 384 usaha. Industri kreatif arsitektur paling banyak di Pulau Sumatera sebesar 893 usaha dan provinsi paling kecil adalah Provinsi Banten sebanyak 138 usaha. Industri kreatif desain interior terbanyak adalah di Jawa Barat sebanyak 141 usaha sedangkan Provinsi Banten adalah yang paling kecil sebanyak 29 unit. Industri kreatif desain komunikasi terbanyak adalah Provinsi DI Yogyakarta sebesar 165 usaha dan Provinsi Sulawesi dan Maluku adalah yang paling sedikit sebesar 11 usaha. Industri kreatif Desain Produk terbesar adalah Provinsi Jawa Barat sebanyak 691 usaha dan Pulau Sulawesi dan Maluku adalah yang terkecil sebesar 64 usaha. Industri kreatif fesyen terbanyak berada di Pulau Sumatera sebanyak 232,118 usaha dan Provinsi DI Yogyakarta sebanyak 22,500 unit.

Industri kreatif Film, Animasi dan Video terbesar berada di Pulau Sumatra sebanyak 468 usaha dan jumlah usaha terkecil berada di Banten sebanyak 47 usaha. Industri kreatif fotograsi terbanyak berada di Pulau Sumatera 9,391 usaha dan paling sedikit berada di Provinsi Banten sebesar 805 usaha. Industri kreatif kriya usaha terbanyak berada di Provinsi Jawa Tengah 296,033 dan terkecil berada di 
Provinsi Banten sebesar 21,965. Industri kreatif kuliner terbanyak berada di Jawa Barat sebesar 1,086,602 dan tersedikit berada di Provinsi DI Yogyakarta sebesar 105,568 usaha

. Industri kreatif musik terbanyak di Pulau Sumatera sebanyak 7,849 usaha dan tersedikit berada di Provinsi DI Yogyakarta sebesar 802 usaha. Industri kreatif penerbitan terbanyak berada di Provinsi Jawa Timur sebesar 16,805 usaha dan tersedikit Provinsi Banten sejumlah 2,742 usaha. Industri kreatif periklanan terbesar berada di Provinsi DKI Jakarta1,292 usaha dan terkecil berada di Pulau Kalimantan sejumlah 71 usaha. Industri kreatif seni pertunjukan terbesar berada di 16,805 usaha dan terkecil berada di Provinsi Banten sejumlah 603 usaha. Industri kreatif seni rupa terbesar berada di 3,643 usaha dan terkecil berada di 421 usaha. Industri kreatif televisi dan radio terbesar di 987 usaha dan terkecil berada di 70 usaha. Total keseluruhan provinsi dan pulau yang terbanyak berada di 1,504,103 usaha dan terkecil berada di 299,385 usaha. Industri kreatif terbesar pada Kuliner dengan 5,550,960 usaha dan terkecil pada Desain Komunikasi dengan 616 usaha.

Dari kemajuan yang terus meningkat dari UMKM dan industri kreatif maka penelitian ini tertarik untuk melihat bagaimanakah model e-bisnis yang dimiliki oleh Modalku dan Blanja.com dalam mendorong pertumbuhan UMKM dan industri kreatif. Sekaligus peneliti ingin melihat tidak hanya model bisnisnya namun kebijakan apa yang mendukung berdirinya perusahaan tersebut dan pedomannya dalam melaksanakan aktivitas ebisnis harian.

\section{TELAAH LITERATUR DAN PENGEMBANGAN HIPOTESIS}

\section{e Business Model}

Model bisnis menjelaskan alasan bagaimana suatu organisasi menciptakan, memberikan, dan menangkap nilai (Osterwalder, Pigneur, 2009). Sementara Fuach \& Tucci (2001) mendefinisikan model bisnis sebagai suatu cara bagaimana perusahaan membangun dan memanfaatkan semua resources yang dimiliki untuk memberikan konsumen nilai tambah (value added) dibandingkan dengan kompetitor. Pengertian lain dari model bisnis (Guo (2016), menjelaskan bahwa model bisnis menggambarkan logika sistem bisnis untuk menciptakan nilai berdasarkan proses bisnis yang aktual. Amit \& Zott (2001) yang dikutip dari Guo (2016) mendefinisikan bahwa model bisnis menggambarkan konten, struktur, dan tata kelola transaksi yang dirancang untuk menciptakan nilai melalui eksploitasi peluang bisnis.

Dengan semakin berkembangnya teknologi, dan internet, dimana transaksi banyak dilakukan secara elektronik, muncul terminologi e business model, yang berarti melakukan bisnis secara elektronik. Istilah model e business model pertama kali didefinisikan oleh IBM pada 1990-an sebagai transformasi dari proses bisnis utama melalui penggunaan teknologi internet (Guo, 2016). Fuach \& 
Tucci (2001) mendefinisikan e business model sebagai suatu cara bagaimana perusahaan mendapatkan uang dengan menggunakan internet.

Osterwalder dan Pigneur (2002) menemukan kerangka kerja e business model yang dijabarkan ke dalam empat pilar utama, yaitu: 1) product \& services; 2) infrastructure and the network of partners; 3) customer relationship; dan 4) financial aspects.

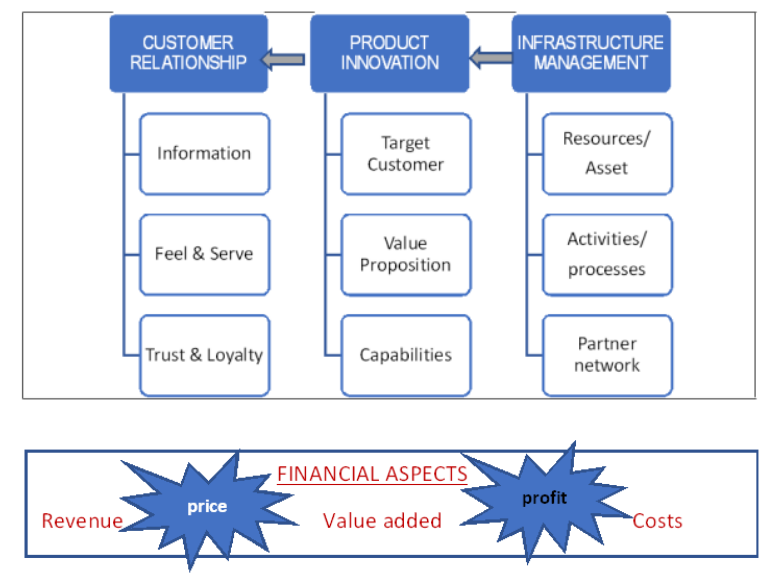

Gambar-1. Kerangka kerja e business model Osterwalder, Pigneur (2002)

\section{Profil Ekonomi Digital}

Perusahaan start up financial technology sudah banyak bermunculan saat ini. Berdasarkan data OJK per bulan Mei 2019, perusahaan Fintech Lending berizin dan terdaftar ada sebanyak 113 perusahaan start up, lima diantaranya adalah perusahaan dengan jenis usaha syariah. Otoritas Jasa Keuangan terus mendorong peran Fintech Lending untuk dapat meningkatkan perluasan akses permodalan khususnya UMKM. OJK terus menerus melakukan penguatan dan medorong industri fintech lending dengan membuat peraturan teknis dan operasional, kolaborasi antara industri jasa keuangan dan melakukan dialog dengan stakeholders terkait dalam rangka meningkatkan regulasi.

Berdasarkan data statistik yang dikeluarkan OJK, jumlah akumulasi rekening, akumulasi transaksi dan jumlah pinjaman menunjukkan tren yang terus bertumbuh. Jumlah akumulasi pinjaman meningkat sebesar 119,69\% dari bulan Desember 2018 sebesar Rp 22,66 triliun menjadi 49,79 triliun di bulan Juli 2019. Jumlah pinjaman paling banyak berasal dari pulau Jawa sebesar Rp. 42,74 triliun, sedangkan dari luar pulau Jawa sebesar 7,048 triliun. Tingkat keberhasilan pengembalian/kualitas pinjaman (TKB90) menunjukkan angka 98,55\% pada bulan Desember 2018, mengalami sedikit penurunan menjadi 97,48\% di bulan Juli 2019.

Sementara berdasarkan laporan yang dbuat oleh McKinsey (2018), perdagangan online di Indonesia mencapai sekitar \$ $5 \mathrm{M}$ untuk e-tailing formal, transaksi yang dilakukan melalui market place e tailing seperti bukalapak, tokopedia, dan sebesar $\$ 3 \mathrm{M}$ melalui e tailing informal, seperti facebook 
atau instagram. Diperkirakan ada sekitar 30 juta online di tahun 2017. Ada lima tren yang mendorong perdagangan online di Indonesia: 1) terbukanya pasar melalui telepon cerdas; 2) konsumen muda yang cerdas secara digital; 3) meningkatkan partisipasi UMKM dalam transaksi perdagangan online; 4) meningkatnya investasi dalam perdagangan online; dan 5) kebijakan pemerintah yang mendukung.

\section{e Business Model perusahaan start up Fintech}

Dengan menggunakan e business model Pigneur dan Osterwalder, beberapa perusahaan start up fintech yang dipilih sebagai objek penelitian, dilakukan mapping dan deskripsi data sesuai dengan informasi yang di dapat dari masing-masing website perusahaan start-up fintect berdasarkan empat pilar dan elemen utamanya. Setelah itu kemudian di analisis dan disimpulkan yang berlaku umum untuk semua perusahaan start up fintech sebagai objek penelitian.

Pilar utama adalah product innovation dengan elemen utamanya target customer, value proposition, dan capabilities. Berdasarkan informasi yang di dapat dari masing-masing website perusahaan fintech yang menjadi objek penelitian, kategori produk perusahaan fintech adalah peer to peer lending. Model bisnis dikenal juga sebagai model bisnis crowdfunding. Seperti hal-nya perusahaan penyedia jasa keuangan bank, perusahaan fintech adalah mediator antara pemilik dana dengan yang membutuhkan dana. Perbedaannya adalah di prosedur layanan keuangan. Fintech menyediakan platform real time untuk layanan keuangannya, baik untuk peminjam atau pendana.

Target customer perusahaan start up peer to peer lending adalah pemilik dana dan peminjam. Peminjam diutamakan pada sektor UMKM yang memang memerlukan akses kepada pembiayaan yang mudah, murah dan dapat membantu memberikan modal kerja. Sementara pemilik dana adalah ditargetkan kepada semua orang yang memiliki dana, dan mempunyai perhatian terhadap pertumbuhan UMKM, disamping itu dari sisi bisnis akan mendapatkan return dari pendanaan yang diberikan.

Value proposition yang dapat diberikan oleh perusahaan fintech terhadap UMKM adalah kemudahan administrasi untuk mendapatkan modal kerja dengan cepat, dan dengan tingkat bunga pinjaman yang kompetitif. Penyaluran pinjaman untuk UMKM per januari 2019 telah mencapai Rp 25,9 triliun melalui peer to peer lending (okezone.com, 2019). Di sisi lain untuk dapat memberikan value yang lebih baik, perlu dilakukan literasi keuangan dan edukasi kepada pelaku bisnis UMKM terkait jasa layanan fintech dan perlindungan konsumen terhadap resiko yang ada. $E$ business model perusahaan e commerce. Beberapa perusahaan Fintech untuk UMKM dan Industri Kreatif yaitu : Modalku, Amartha, Investree, Koinworks, Crowdo. Dan beberapa perusahaan e-commerce untuk UMKM antara lain : UKMMarket.co.id, Usahadesa.com, Cipika Store, Kriya, GaleriPos, Blanja.com. 


\section{Product Innovation}

Pilar pertama dari kerangka kerja e businees model Pigneur (2002) adalah inovasi produk. Pilar pertama ini memiliki tiga elemen utama, yaitu value proposition, target customer, dan capabilities.

Value proposition mengacu pada nilai apa yang dapat diberikan perusahaan kepada segmen target pelanggan tertentu. Dengan adanya lompatan kemajuan teknologi dan internet memberikan peluang yang baru untuk menciptakan nilai di satu sisi dan efisiensi penciptaan nilai di sisi yang lain. Perusahaan dapat melakukan diferensiasi dibanding dengan pesaing. Pertama adalah difererensiasi produk, dalam hal membuat produk dan jasa yang baru dan inovatif, melayani pesanan khusus sesuai dengan permintaan pelanggan. Perusahaan juga dapat memasukkan komponen informasi baru terkait produk dan jasa yang ditawarkan kepada konsumen. Kedua, adalah diferensiasi harga yang lebih rendah dari kompetitor. Penghematan biaya dicapai melalui dioptimalkan manajemen infrastruktur atau penjualan langsung melalui Internet. Ketiga, kemampuan untuk memberikan jasa dan layanan premium kepada konsumen.

Target Customer mengacu kepada target pelanggan tertentu yang hendak dituju. Perusahaan menciptakan nilai untuk segmen pelanggan tertentu. Interaksi bisnis dan transaksi antara perusahaan dengan pelanggan berdasarkan e business model dapat berupa hubungan Business to Business (B2B), Business to Customer (B2C), atau Customer to Customer (C2C). Sementara segmen pelanggan dapat dibagi menjadi beberapa segmen, yaitu: 1) mass market; 2) niche market; 3) segmented; 4) diversified; 5) multi-sided platforms (Nizar, 2017).

Capabilities adalah kemampuan perusahaan memberikan value proposition kepada pelanggan. Capabilities dapat juga dipahami sebagai pola tindakan yang berulang di dalam pengelolaan aset untuk menciptakan, menghasilkan dan menawarkan produk dan layanan ke pasar.

\section{Infrastructure Management}

Pilar kedua dari kerangka kerja ini adalah infrastructure management. Pilar kedua ini terdiri dari elemen activity configuration, resources and assets dan partner network. Pilar kedua ini menggambarkan bagaimana perusahaan di dalam membangun dan mengelola infrastruktur perusahaan agar dapat memberikan value proposition kepada pelanggan.

Activity configuration adalah konfigurasi aktivitas dan proses perusahaan bagaimana menghubungkan dan memberikan layanan transaksi antara pembeli dan penjual dengan teknologi berbasis internet. Pada elemen ini tujuannya adalah mewujudkan supply chain management, untuk merancang, mendesain, dan kontrol arus material dan informasi sepanjang rantai pasokan dengan tujuan kepuasan konsumen. 
Partner network menggambarkan hubungan antara perusahaan dengan mitra bisnis yang bersifat strategis dan stabil. Hubungan yang baik dengan mitra bisnis sangat penting agar perusahaan dapat kosentrasi pada kompentensi inti perusahaan sesuai dengan konfigurasi aktivitas perusahaan. Kerja sama dengan mitra bisnis bisa dalam bentuk aliansi strategis, usaha patungan, kemitraan pembeli-pemasok jangka panjang, dan bentuk ikatan kerja sama lainnya.

Resources and Assets menjelaskan bagaimana penggunaan semua sumber daya dan aset milik perusahaan, baik dalam bentuk aset berwujud, aset tidak berwujud dan sumber daya manusia ditujukan untuk menciptakan nilai (value) baik kepada perusahaan, mitra bisnis, dan pelanggan.

\section{Customer Relationship}

Pada pilar ini, menggambarkan bagaimana perusahaan berbasis internet menjaga hubungan dengan pelanggan. Ada tiga elemen pada pilar ketiga ini, yaitu: 1) information strategy; 2) feel \& serve (distribution channel); 3) trust \& loyalty.

Ada tiga tujuan information strategy. Pertama, mengumpulkan informasi pelanggan. Kedua cara menggunakan informasi untuk mendapatkan nilai lebih di dalam hubungan dengan pelanggan. Ketiga, menggunakan informasi yang tepat untuk mendapatkan peluang bisnis baru yang menguntungkan dan memberikan kepuasan kepada pelanggan.

Feel \& Serve (distribution channels) menjelaskan bagaimana perusahaan mendefinisikan strategi untuk mendapatkan pelanggan melalui saluran-saluran (channels) yang ada baik langsung maupun tidak langsung, yang disediakan oleh perusahaan maupun pihak ketiga (agen, perantara). Tujuan dari strategi channels adalah untuk menyediakan jumlah yang tepat dari produk dan jasa layanan, di tempat yang tepat, waktu yang tepat dan target pelanggan yang tepat.

Trust \& Loyalty adalah kepercayaan dan kesetiaan yang terus dibangun dan dijaga perusahaan terhadap mitra bisnis, pelanggan dan pihak-pihak yang terlibat dalam melakukan bisnis. Pada $e$ business model, dimana proses bisnis dan transaksi berbasis teknologi dan internet dimana pelaku bisnis tidak selalu berhadapan secara fisik, membuat faktor kepercayaan merupakan hal yang mutlak dilakukan oleh perusahaan dan pelaku usaha yang melakukan bisnis berbasis teknologi dan internet. Kepercayaan yang mampu dibangun, dipertahankan, dan kemampuan memberikan kepuasan pelanggan oleh perusahaan akan mampu menghasilkan loyalitas pelanggan.

\section{Financial Aspects}

Financial aspects adalah pilar keempat dari kerangka kerja e business model Osterwalder dan Pigneur (2002). Pilar ini terdiri dari 3 elemen, yaitu revenue model, cost structure dan profit model.

Revenue model mengukur kemampuan perusahaan di dalam menghasilkan pendapatan dari penjualan produk dan jasa layanan kepada pelanggan. Pada perusahaan penyedia jasa keuangan 
berbasis internet, aliran pendapatan di dapat dari pendapatan bunga dan biaya jasa layanan keuangan. Pada perusahaan e Commerce aliran pendapatan bisa berasal dari fee per transaksi dan pendapatan iklan (Nizar, 2017). Cost Structure mengukur semua biaya yang dikeluarkan perusahaan untuk menciptakan, memasarkan dan memberikan nilai kepada pelanggan. Sementara Profit model adalah hasil dari perbedaan antara model pendapatan dan struktur biaya.

\section{METODE PENELITIAN}

\section{Jenis Penelitian}

Jenis penelitian ini adalah penelitian kualitatif yang bersifat studi pustaka (library research) yang menggunakan model ebisnis Osterwalder dan Pigner sebagai pembanding antara perusahaan Fintech dan Ecommerce yang mendukung UMKM dan industri kreatif. Waktu penelitian dilakukan pada September 2019 dari URL perusahaan Fintech dan Ecommerce yang digunakan UMKM dan industri kreatif. Subjek penelitian adalah prusahaan Fintech untuk UMKM adalah Modalku. Perusahaan e-Commerce untuk UMKM adalah Blanja.com

\section{Prosedur}

Prosedur yang dilakukan dalam penelitian ini adalah : (1) Mencari sumber data sekunder dari internet, (2) Mencari Paket Kebijakan fintech dan e-commerce, (3) Memilih obyek penelitian untuk UMKM yang menggunakan fintech dan e-commerc, (4) Mengakses url fintech dan e-commerce untuk UMKM dan industri kreatif yang berpartner dengan UMKM, (5) Mendeskripsikan obyek penelitian dengan model e-bisnis Osterwalder dan Pigner, (6) Menyelaraskan antara kebijakan, pedoman umum, pelaksanaan, dan evaluasi.

\section{Data, Instrumen dan Teknik Pengumpulan Data}

Data yang digunakan adalah data sekunder yang berasal dari internet. Instrumen yang digunakan adalah model e-bisnis Osterwalder dan Pigner. Teknik pengumpulan data dengan browsing dari internat untuk mencari kebijakan, pedoman, dan pelaksanaannya.

\section{Teknik Pengolahan Data}

Teknik pengolahan data digambarkan pada gambar 2 berikut ini :

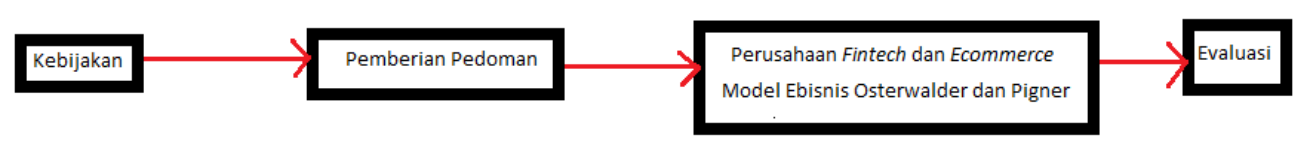

Gambar 2. Teknik Pengolahan Data

1. Kebijakan adalah peraturan yang dibuat oleh pemerintah dalam hal ini OJK untuk mengatur dan menyelesaikan hambatan-hambatan tertentu yang disebabkan ada permasalahan. 
2. Pemberian pedoman merupakan pemberian acuan tertulis oleh OJK untuk pelaksanaan Fintech dan E-commerce

3. Pelaksanaan merupakan berjalannya proses Fintech dan Ecommerce berdasarkan pedoman dan model e-binis Osterwalder dan Pigner.

4. Evaluasi: Penilaian model e-bisnis Osterwalder dan Pigner, kebijakan Pemerintah, procedural yang dimiliki dalam proses Fintech dan e-Commerce untuk mendukung pertumbuhan UMKM dan Industri Kreatif.

\section{HASIL PENELITIAN DAN PEMBAHASAN}

\section{Profil Ekonomi Digital}

Perusahaan start up financial technology sudah banyak bermunculan saat ini. Berdasarkan data OJK per bulan Mei 2019, perusahaan Fintech Lending berizin dan terdaftar ada sebanyak 113 perusahaan start up, lima diantaranya adalah perusahaan dengan jenis usaha syariah. Otoritas Jasa Keuangan terus mendorong peran Fintech Lending untuk dapat meningkatkan perluasan akses permodalan khususnya UMKM. OJK terus menerus melakukan penguatan dan medorong industri fintech lending dengan membuat peraturan teknis dan operasional, kolaborasi antara industri jasa keuangan dan melakukan dialog dengan stakeholders terkait dalam rangka meningkatkan regulasi.

Berdasarkan data statistik yang dikeluarkan OJK, jumlah akumulasi rekening, akumulasi transaksi dan jumlah pinjaman menunjukkan tren yang terus bertumbuh. Jumlah akumulasi pinjaman meningkat sebesar 119,69\% dari bulan Desember 2018 sebesar Rp 22,66 triliun menjadi 49,79 triliun di bulan Juli 2019. Jumlah pinjaman paling banyak berasal dari pulau Jawa sebesar Rp. 42,74 triliun, sedangkan dari luar pulau Jawa sebesar 7,048 triliun. Tingkat keberhasilan pengembalian/kualitas pinjaman (TKB90) menunjukkan angka 98,55\% pada bulan Desember 2018, mengalami sedikit penurunan menjadi 97,48\% di bulan Juli 2019.

Sementara berdasarkan laporan yang dbuat oleh McKinsey (2018), perdagangan online di Indonesia mencapai sekitar \$ $5 \mathrm{M}$ untuk e-tailing formal, transaksi yang dilakukan melalui market place e tailing seperti bukalapak, tokopedia, dan sebesar \$ $3 \mathrm{M}$ melalui e-tailing informal, seperti facebook atau instagram. Diperkirakan ada sekitar 30 juta online di tahun 2017. Ada lima tren yang mendorong perdagangan online di Indonesia: 1) terbukanya pasar melalui telepon cerdas; 2) konsumen muda yang cerdas secara digital; 3) meningkatkan partisipasi UMKM dalam transaksi perdagangan online; 4) meningkatnya investasi dalam perdagangan online; dan 5) kebijakan pemerintah yang mendukung.

\section{e Business Model perusahaan start up Fintech}

Dengan menggunakan e business model Pigneur dan Osterwalder, beberapa perusahaan start up fintech yang dipilih sebagai objek penelitian, dilakukan mapping dan deskripsi data sesuai dengan 
informasi yang di dapat dari masing-masing website perusahaan start-up fintect berdasarkan empat pilar dan elemen utamanya. Setelah itu kemudian di analisis dan disimpulkan yang berlaku umum untuk semua perusahaan start up fintech sebagai objek penelitian.

Pilar utama adalah product innovation dengan elemen utamanya target customer, value proposition, dan capabilities. Berdasarkan informasi yang di dapat dari masing-masing website perusahaan fintech yang menjadi objek penelitian, kategori produk perusahaan fintech adalah peer to peer lending. Model bisnis dikenal juga sebagai model bisnis crowdfunding. Seperti hal-nya perusahaan penyedia jasa keuangan bank, perusahaan fintech adalah mediator antara pemilik dana dengan yang membutuhkan dana. Perbedaannya adalah di prosedur layanan keuangan. Fintech menyediakan platform real time untuk layanan keuangannya, baik untuk peminjam atau pendana.

Target customer perusahaan start up peer to peer lending adalah pemilik dana dan peminjam. Peminjam diutamakan pada sektor UMKM yang memang memerlukan akses kepada pembiayaan yang mudah, murah dan dapat membantu memberikan modal kerja. Sementara pemilik dana adalah ditargetkan kepada semua orang yang memiliki dana, dan mempunyai perhatian terhadap pertumbuhan UMKM, disamping itu dari sisi bisnis akan mendapatkan return dari pendanaan yang diberikan.

Value proposition yang dapat diberikan oleh perusahaan fintech terhadap UMKM adalah kemudahan administrasi untuk mendapatkan modal kerja dengan cepat, dan dengan tingkat bunga pinjaman yang kompetitif. Penyaluran pinjaman untuk UMKM per januari 2019 telah mencapai Rp 25,9 triliun melalui peer to peer lending (economy.okezone.com, 2019). Di sisi lain untuk dapat memberikan value yang lebih baik, perlu dilakukan literasi keuangan dan edukasi kepada pelaku bisnis UMKM terkait jasa layanan fintech dan perlindungan konsumen terhadap resiko yang ada.

\section{Kebijakan}

PT Mitrausaha Indonesia Grup ("Modalku") telah terdaftar di Otoritas Jasa Keuangan ("OJK") sebagai Penyelenggara Layanan Pinjam Meminjam Uang Berbasis Teknologi Informasi dengan Surat Tanda Bukti Terdaftar dari OJK Nomor S-2493/NB.111/2017 tanggal 31 Mei 2017 sehingga pelaksanaan kegiatan usahanya diawasi secara ketat oleh OJK berdasarkan Peraturan Otoritas Jasa Keuangan Nomor 77/POJK.01/2016 tentang Layanan Pinjam Meminjam Uang Berbasis Teknologi Informasi.

\section{Pedoman}

1. Layanan Pinjam Meminjam Berbasis Teknologi Informasi merupakan kesepakatan perdata antara Pemberi Pinjaman dengan Penerima Pinjaman, sehingga segala risiko yang timbul dari kesepakatan tersebut ditanggung sepenuhnya oleh masing-masing pihak. 
2. Resiko Kredit atau Gagal Bayar dan seluruh kerugian dari atau terkait dengan kesepakatan pinjam meminjam ditanggung sepenuhnya oleh Pemberi Pinjaman. Tidak ada lembaga atau otoritas negara yang bertanggung jawab atas resiko gagal bayar dan kerugian tersebut.

3. Penyelenggara dengan persetujuan dari masing-masing Pengguna (Pemberi Pinjaman dan/atau Penerima Pinjaman) mengakses, memperoleh, menyimpan, mengelola dan/atau menggunakan data pribadi Pengguna ('Pemanfaatan Data') pada atau di dalam benda, perangkat elektronik (termasuk smartphone atau telepon seluler), perangkat keras (hardware) maupun lunak (software), dokumen elektronik, aplikasi atau sistem elektronik milik Pengguna atau yang dikuasai Pengguna, dengan memberitahukan tujuan, batasan dan mekanisme Pemanfaatan Data tersebut kepada Pengguna yang bersangkutan sebelum memperoleh persetujuan yang dimaksud.

4. Pemberi Pinjaman yang belum memiliki pengetahuan dan pengalaman pinjam meminjam, disarankan untuk tidak menggunakan layanan ini.

5. Penerima Pinjaman harus mempertimbangkan tingkat bunga pinjaman dan biaya lainnya sesuai dengan kemampuan dalam melunasi pinjaman.

6. Setiap kecurangan tercatat secara digital di dunia maya dan dapat diketahui masyarakat luas di media sosial.

7. Pengguna harus membaca dan memahami informasi ini sebelum membuat keputusan menjadi Pemberi Pinjaman atau Penerima Pinjaman

8. Pemerintah yaitu dalam hal ini Otoritas Jasa Keuangan,tidak bertanggung jawab atas setiap pelanggaran atau ketidakpatuhan oleh Pengguna,baik Pemberi Pinjaman maupun Penerima Pinjaman(baik karena kesengajaan atau kelalaian Pengguna)terhadap ketentuan peraturan perundang-undangan maupun kesepakatan atau perikatan antara Penyelenggara dengan Pemberi Pinjaman dan/atau Penerima Pinjaman.

9. Setiap transaksi dan kegiatan pinjam meminjam atau pelaksanaan kesepakatan mengenai pinjam meminjam antara atau yang melibatkan Penyelenggara,Pemberi Pinjaman dan/atau Penerima Pinjaman wajib dilakukan melalui escrow account dan virtual account sebagai mana yang diwajibkan berdasarkan Peraturan Otoritas Jasa Keuangan Nomor77/POJK.01/2016 tentang Layanan Pinjam Meminjam Uang Berbasis Teknologi Informasi dan pelanggaran atau ketidakpatuhan terhadap ketentuan tersebut merupakan bukti telah terjadinya pelanggaran hukum oleh Penyelenggara sehingga Penyelenggara wajib menanggung ganti rugi yang diderita oleh masing-masing Pengguna sebagai akibat langsung dari pelanggaran hukum tersebut diatas tanpa mengurangi hak Pengguna yang menderita kerugian menurut Kitab Undang-Undang Hukum Perdata. 


\section{Pelaksanaan}

Berikut adalah pelaksanaan perusahaan Fintech untuk UMKM dan Industri Kreatif :

\section{Modalku}

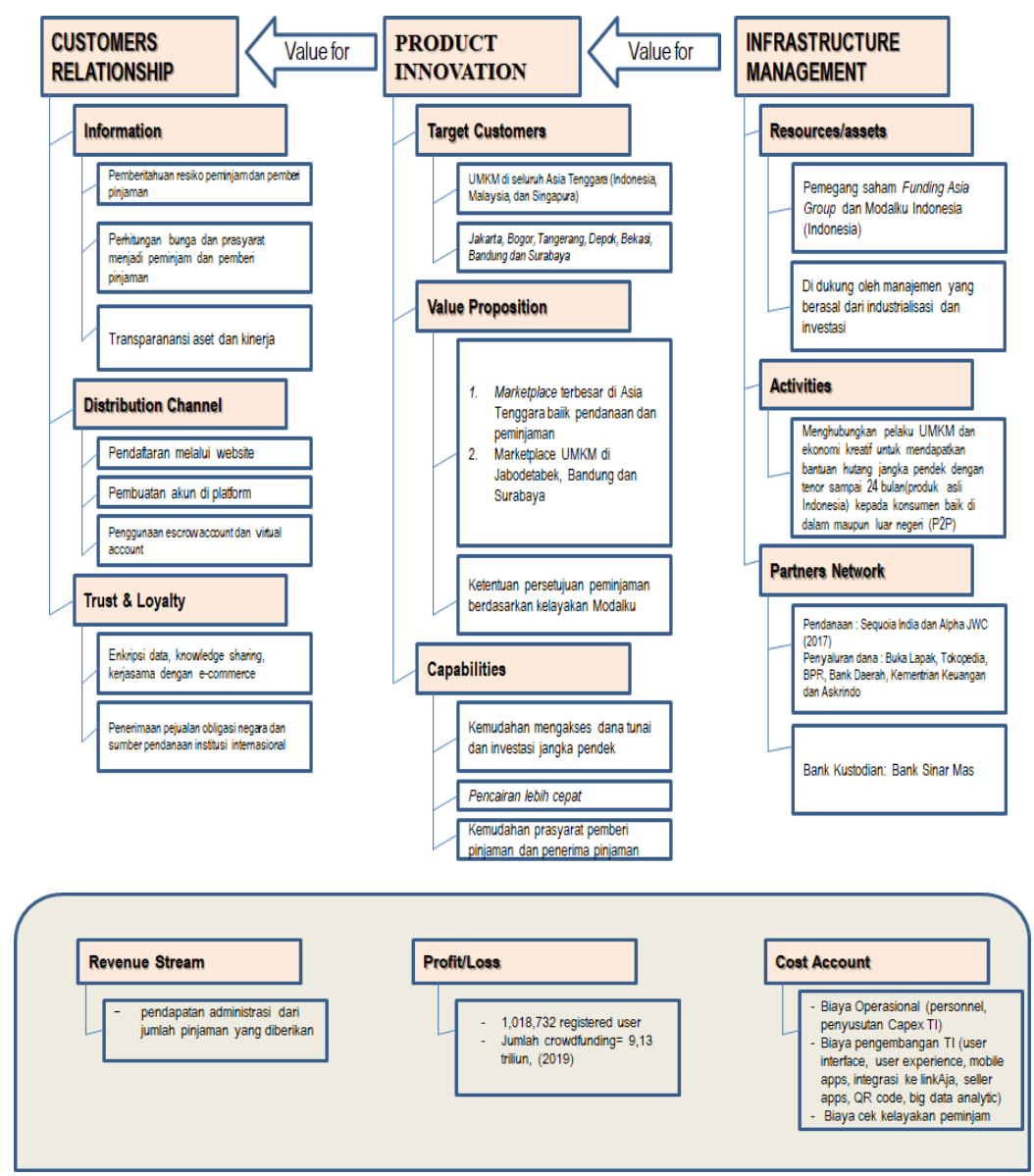

Gambar 3. Pelaksanaan Model Oster-pigneur Modalku

\section{Evaluasi}

Modalku memiliki kemampuan manajemen yang berasal dari industrialisasi dan investasi yang dimiliki oleh dua perusahaan yaitu Funding Asia Group dan Modalku Makmur Indonesia yang memiliki aktivitas menghubungkan antar pemberi pinjaman dengan pelaku UMKM dan pelaku ekonomi kreatif untuk pembiayaan jangka pendek. Jaringannya sudah mulai ada yang berkenan melakukan pendanaan dua institusi internasional dan penyalurannya tidak hanya dari platform modalku namun juga Buka Lapak, Tokopedia, BPR, Bank Daerah, Kementrian Keuangan dan Askrindo juga Bank Sinar Mas sebagai Bank Kustodian.

Modalku juga memiliki target customers yaitu UMKM seluruh Asia Tenggara. Namun di Indonesia masih terbatas di Jakarta, Bogor, Tangerang, Depok, Bekasi, Bandung, dan Surabaya. Nilai yang ditawarkan adalah marketplace yang terbatas di Jabodetabek, Bandung dan Surabaya dan penentuan persetujuan diterima pinjaman berdasarkan kelayakan Modalku. Kemampuan Modalku 
adalah kemudahan mengakses dana tunai dan investasi jangka pendek, pencairan lebih cepat dan kemudahan prasyarat pinjaman dan penerima pinjaman.

Untuk informasi diberitahukan mengenai risiko yang dihadapi oleh pemberi pinjaman, perhitungan bunga, dan transparansi asset dan kinerja. Untuk saluran distribusi dilakukan di platform, pembuatan akun di platform, penggunaan escrow account dan virtual account. Kepercayaan dan Loyalitas dilakukan dengan cara enkripsi data, knowledge sharing, kerjasama dengan e-commerce, penerimaan penjualan obligasi dan sumber pendanaan institusi internasional.

Pendapatan berasal dari pemotongan dari jumlah uang yang dipinjamkan. Sampai sekarang sudah 1,018,732 dengan penyaluran sebesar 9.13 triliun. Biaya yang keluar biasanya adalah biaya cek kelayakan peminjam.

\section{Blanja.com}

\section{Kebijakan}

Peraturan Presiden Republik Indonesia Nomor 74 Tahun 2017 Tentang Peta Jalan Sistem Perdagangan Nasional Berbasis Elektronik (Road Map E-Commerce) Tahun 2017- 2019

\section{Pedoman}

Berikut peraturan bagi seluruh anggota blanja.com, baik Pembeli dan Penjual, wajib mengetahui dan melaksanakannya. Peraturan ini dibuat untuk melindungi dan menjaga keamanan blanja.com untuk membeli, menjual, dan berpartisipasi dalam komunitas.

\section{Aturan Umum Untuk Anggota}

Anggota blanja.com tidak diperbolehkan untuk :

1. "Merusak situs blanja.com"

2. "Menggunakan umpatan di dalam situs"

3. "Melanggar hak atas kekayaan intelektual di blanja.com"

4. "Membuat akun baru atau membeli dan menjual pada akun lain untuk menghindari penolakan atau pembatasan"

5. "Membuat penawaran untuk membeli dan menjual diluar situs blanja.com"

6. "Laporan kesalahan blanja.com bagi anggota blanja.com lain yang melakukan pelanggaran kebijakan".

Sebagai tambahan aturan bagi anggota blanja.com, blanja.com juga mempunyai aturan spesifik terkait pembelian dan penjualan. 


\section{Aturan Mengenai Identitas}

Anggota blanja.com:

1. "Harus berusia minimal 18 tahun"

2. "Perwakilan identitas tidak diperbolehkan"

3. "Harus selalu memberikan kontak informasi yang valid dan lengkap serta memiliki alamat email yang jelas"

4. "Tidak dapat mempublikasikan kontak informasi anggota lain di area publik"

\section{Aturan Tentang Berkomunikasi Dengan Anggota Blanja.Com Lain}

User blanja.com tidak boleh mengirimkan kepada user lain.

\section{Aturan Mengenai Tanggung Jawab Di blanja.com}

1. "Kebijakan Privasi blanja.com menjelaskan bagaimana informasi pribadi dipergunakan". "Lampiran daftar Kebijakan Pribadi yang dapat diakses pihak ketiga untuk mendapatkan informasi".

2. "Blanja.com menghargai ide Anda, namun hal ini tidak bersifat mengikat"

\section{Pelaksanaan}

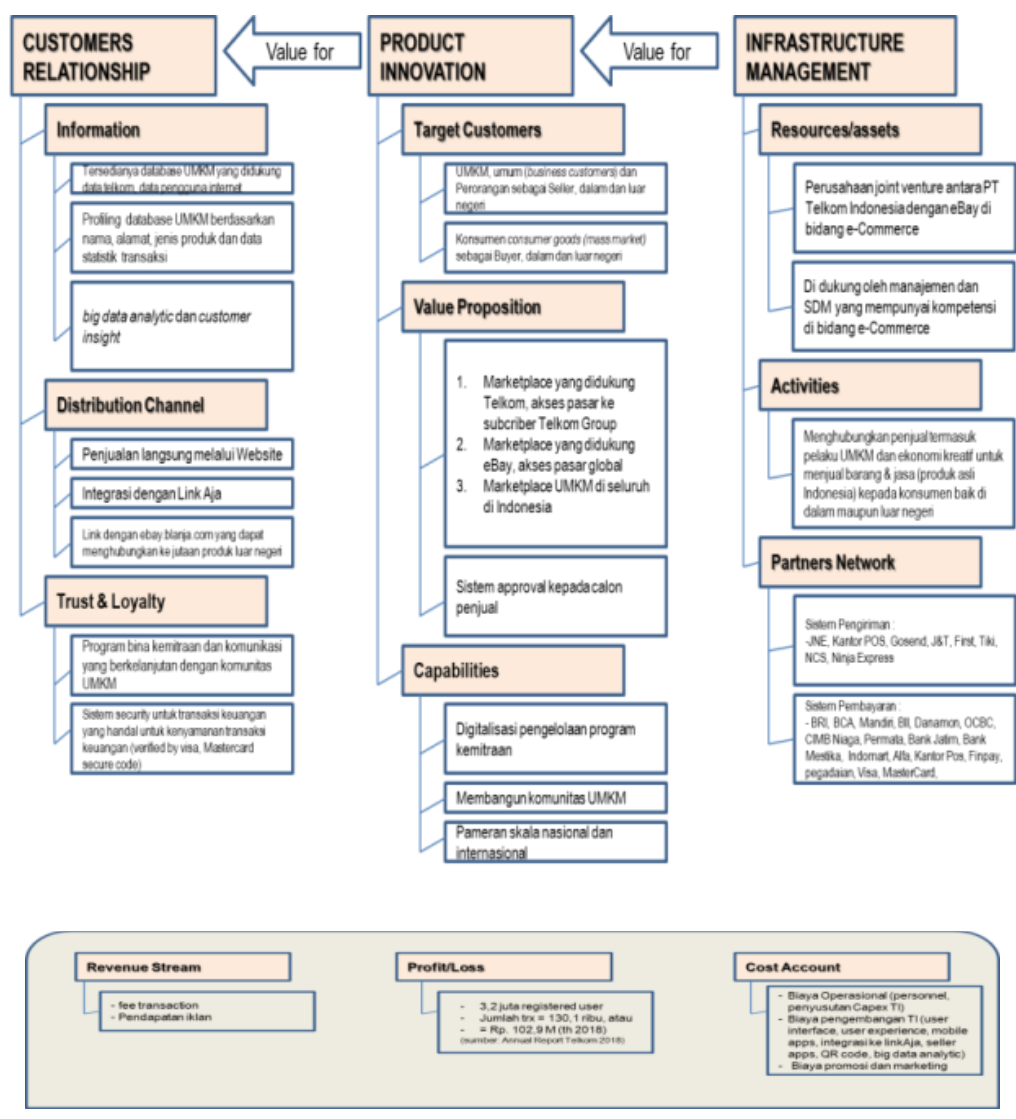

Gambar 4. Pelaksanaan Model Oster-pigneur Blanja.com 


\section{Evaluasi}

Model E-bisnis Blanja.com menurut osterwalder dan pigneur memiliki infrastructure management yang didukung oleh manajemen SDM yang mempunyai kompetensi bidang e-commerce dan perusahaan merupakan joint venture antara PT Telkom Indonesia dengan eBay. Aktivitas yang utama adalah menghubungkan penjual yang merupakan pelaku UKM dan ekonomi kreatif kepada konsumen di dalam dan luar negeri. Jaringan kerjasamanya juga terdiri atas dua yaitu sistem pengiriman dan sistem pembayaran. Sistem pengiriman menggunakan JNE, Kantor POS, Gosend, J\&T, First, Tiki, NCS, dan Ninja Express. Kemudian, sistem pembayaran menggunakan BRI, BCA, Mandiri, BII, Danamon, OCBC, CIMB Niaga, Bank Jatim, Bank Mestika, Indomaret, Alfa, Kantor Pos, Finpay, pegadaian, Visa, dan Mastercard.

Infrastructure management memberikan nilai ke product innovation. Product innovation terdiri atas target customers, value proposition dan capabilities. Target customers adalah UMKM, umum dan perorangan sebagai seller, dalam dan luar negeri serta buyer yaitu konsumen consumer goods, dari dalam dan luar negeri. Value proposition adalah market place yang didukung oleh Telkom dan modal yang berada di seluruh Indonesia. Capabilities adalah Digitalisasi pengelolaan program kemitraan, membangun komunitas UMKM, dan pameran skala nasional dan internasional.

Product innovation memberikan nilai kepada customer relationship terdiri atas information, distribution channel dan trust \& loyalty. Information terdiri atas tersedianya database UKM yang didukung data Telkom dan data pengguna internet; Profiling database IMKM berdasarkan nama, jenis produk dan data statistic transaksi; big data analysis dan costumer insight. Distribution channel melakukan penjualan langsung melalui website,integrasi dengn link saja. Link dengan eBay blanja.com yang dapat membutuhkan ke jutaan produk luar negeri. Terakhir trust dan loyalty adalah program bina kemitraan dan komunikasi yang berkelanjutan dengan komunitas UMKM.

Revenue stream memiliki fee transaction dan pendapatan iklan. Profit/loss adalah 3,2 juta registered user dengan dari fee transaction jumlah sekitarnya dana biayanya sebesar 102,9 M. akuntansi biaya yaitu, biaya yang terdiri atas: biaya operasional, biaya pengembangan, biaya promosi dan marketing.

\section{SIMPULAN}

\section{Simpulan}

Keberadaan Modalku membuat mudah bagi UMKM dan Industri Kreatif untuk mendapatkan dana Jangka pendek dengan kepemimpinan yang memiliki ketrampilan yang baik di sektor industri dan investasi. Modalku bekerjasama dengan Platform e-commerce, Bank Daerah dan BPR dalam memberikan penyaluran uang dari pemyimpan dana. Juga memberikan kesempatan pendana untuk 
membeli ORI dalam membentuk portofolio bebas risiko dan menggunakan Askrindo untuk asuransinya. Dalam menyimpan dana bagi para pendana oleh salah satu Bank di Indonesia. Juga, biaya untuk penggunaan Modalku masih murah sehingga membantu para pendana dan peminjam untuk berinvestasi dan mendapatkan pinjaman maksimal dua tahun. Selain itu, Modalku juga merupakan anggota dari OJK dimana fungsi OJK adalah mengatur, mengelola, menyidik dan investigasi segala kegiatan yang dilakukan Modalku.

Blanja.com dalam mendukung pertumbuhan di industri kreatif dan UMKM didukung oleh Peraturan Presiden Republik Indonesia Nomor 74 Tahun 2017 Tentang Peta Jalan Sistem Perdagangan Nasional Berbasis Elektronik (Road Map e-Commerce) Tahun 2017-2019. Blanja.com sangat melindungi dan menjaga keamanan blanja.com untuk membeli dan menjual serta berpartisipasi dalam komunitas sehingga adanya kemudahan terjadinya pertemuan pembeli dan penjual yang disertai oleh sistem pembayaran dan pengiriman terpercaya.

\section{Saran}

Kurang luasnya cakupan pendistribusian dana oleh Modalku dan sebaiknya lebih ditingkatkan big data bagi blanja.com untuk meningkatkan transaksi. Sebagai tambahan, dalam meningkatkan kepercayaan publik salah satunya dengan menerbitkan laporan keuangan.

\section{Implikasi dan Keterbatasan}

Penelitian ini memberikan implikasi bahwa fintech dan e-commerce merupakan alat bantu untuk UMKM dan Industri Kreatif mendapatkan kemudahan dana pinjaman, investasi dan penjualan produk. Keterbatasan di penelitian ini adalah hanya membahas dua perusahaan untuk fintech (Modalku) dan untuk e-commerce (Blanja.com). Kemudian, kurangnya sumber data pengguna Modalku dan Blanja.com sehingga penelitian ini hanya sebatas kualitatif.

\section{DAFTAR PUSTAKA}

Blanja.com. n.d. Retrieved 08 22, 2019, from Blanja.com website: https://marketing.co.id/marketplace-kolaborasi-telkom-dan-ebay/

Blanja.com. n.d.. Retrieved 09 22, 2019, Blanja.com Website: https://www.blanja.com/help/questionlist-45-0

Indonesia.n.d.. PERATURAN PRESIDEN REPUBLIK INDONESIA NOMOR 74 TAHUN 2017 TENTANG PETA JALAN SISTEM PERDAGANGAN NASIONAL BERBASIS ELEKTRONIK (ROAD MAP E-COMMERCE) TAHUN 2017-2019. Retrieved 09 22, 2019, from Kemenkeu Website: https://idih.kemenkeu.go.id/fullText/2017/74TAHUN2017PERPRES.pdf 
KPMG. 2018. The Fintech Edge First Edition: Peer-to-Peer Lending. Kpmg.com/id, KPMG Siddharta Advisory

Modalku. n.d. Retrieved 09 22, 2019, Modalku Website: https://modalku.co.id/

Modalku. n.d.. Retrieved 09 22, 2019, Modalku Website: https://modalku.co.id/about-us

Nizar, N.I. 2017. Analisis Model Bisnis Dan Strategi Perusahaan Start Up E-Commerce Studi Kasus Pada Gerobakonline.Com, Jurnal Mandiri, J. Mandiri., Vol. 1, No. 1, Juni 2017 (99 - 113), (C2017 Lembaga Kajian Demokrasi dan Pemberdayaan Masyarakat (LKD-PM)

Okezone .n.d. Retrieved 08 30, 2019, from Okezone Website: https://economy.okezone.com/read/2019/03/26/320/2035162/ojk-fintech-salurkanpembiayaan-ke-umkm-tembus-rp25-9-triliun

Osterwarder, A. Pigneur, Y. 2002. An e-Business Model, Ontology for Modeling e-Business, 15th Bled Electronic Commerce Conference, Bled, Slovenia, June 17 - 19, 2002

Osterwarder, A. Pigneur, Y. 2009. Business Model Generation, Self Published. The Netherlands: Modderman Drukwerk Amsterdam.

PwC Indonesia. 2019. Indonesia's Fintech Lending: Driving Economic Growth Through Financial Inclusion. Retrieved 09 01, 2019, from Website: www.pwc.com/id/fintech-lending

Radio Elshinta. n.d.. Retrieved 09 26, 2019, from Elshinta Website: https://elshinta.com/news/154365/2018/08/30/ada-16-subsektor-ekonomi-kreatif-apasajakah-itu 